\title{
Effect supplementation of urea molasse multinutrient block (UMMB) on the weight gain average of Heifers Peranakan Ongole breed
}

\author{
Yanuartono*, Alfarisa Nururrozi, Soedarmanto Indarjulianto, \\ Hary Purnamaningsih, Nurman Haribowo, and \\ Adhit Dwi Oktawan
}

Department Internal Medicine, Faculty of Veterinary Medicine,

Universitas Gadjah Mada, Jl. Olahraga, Yogyakarta, Indonesia 55281

*e-mail: yanuartono20@yahoo.com

\begin{abstract}
An experiment was conducted to evaluate the effects supplementation of urea-molasse multinutrient block (UMMB) on the weight gain of heifers peranakan ongole beef cattle based diets with rice straw. Urea molasse multinutrient block were made with different formulations (A and B). A total of 15 heifers Peranakan Ongole beef cattle were divided into 3 groups. Control group animals were daily fed rice straw as a basal diet without UMMB, group A were daily fed rice straw as a basal diet with UMMB (A), group $B$ were daily fed rice straw as a basal diet with UMMB (B) respectively. Weight gain were measured with Lambourne method weekly. Data on the feeding trial were collected during $4 \mathrm{wk}$, and were subjected to the Paired T-test analysis of variance (ANOVA). The results of this experiment showed that the UMMB supplementation had no significantly influenced of weight gain average $(P>0.05)$. With regard to the weight gain average of heifers, the group A showed a highest $(9.52 \mathrm{~kg})$, group B $(9.38 \mathrm{~kg})$ and control group $(6.98 \mathrm{~kg})$, respectively. Based on statistical analyses, it can be concluded that supplementation of UMMB had no effects on average weight gain in this study.
\end{abstract}

\section{Keywords}

Lambourne method, Peranakan ongole beef cattle, supplementation, urea-molasse multinutrient block (UMMB), weight gain

\section{Introduction}

Citation: Yanuartono, Nururrozi, A., Indarjulianto, S., Purnamaningsih, H., Haribowo, N., \& Oktawan, A. D. (2018). Effect supplementation of Urea Molasse Multinutrient Block (UMMB) on the weight gain average of Heifers Peranakan Ongole breed. In T. R. Nuringtyas, A. C. Sukartiko, \& A. Isnansetyo (Eds.), UGM Digital Press Life Sciences: Vol. 1. Proceeding of the 2nd International Conference on Tropical Agriculture, (pp. 39-43).

Published: October, 2018
Livestock farming is crucially important for provision of animal-based food products for the population, and as a source of income for many resource-poor farmers in developing countries. Nutrient deficiency is a commonly problem in the world, especially the mineral deficiencies and imbalances for cattle [1]. Among the constraints faced by the beef cattle farmers, poor nutritional status of has been identified as one of the major obstacles [2]. According to these sources, the basal diets of ruminants during the dry season are fibrous crop residues and pasture, which are low in their nutritional contents. On the other hand, insufficient intake of energy, protein and minerals is associated with sub-optimal productive and reproductive performance of ruminants [3]. The basal diet majority of beef cattle in the district of Gunungkidul, 
DIY Province consists of crop residues, especially rice straw as the main source of energy for cattle. These paddy by products are generally of low quality because of low digestibility and lack of protein. Several solutions have been suggested by researchers to improve the nutritional quality and palatability of low quality rice straw [4]. In order to continue to foster the development of livestock, it is necessary to introduce a variety of appropriate technologies to the public. One of the technologies in the field of animal feed is the use of UMMB as a feed supplement in ruminant livestock. Urea-molasses multi-nutrient block (UMMB) is usually made up of Molasses, urea, cement or lime, bran, eventually protein rich by-products, salt and water which are mixed and processed into the form of a solid and compact block. Generally, UMMB is considered an appropriate supplement with poor quality roughages that are deficient in nitrogen and with poor digestibility, but it may also be useful when animals are given good quality forage. Urea-molasses multi-nutrient block (UMMB) is low-cost technology and has great potential to enhance the nutrition of ruminant livestock in Indonesia and improve ruminant productivity. In several countries, it has been used as a feed supplement for beef cattle, dairy cows and a small ruminant [5]. Urea molasses multi nutrient block (UMMB) can improve the utilization of low quality rice straw by satisfying the requirement of the rumen microorganisms, creating a better environment for the fermentation of fibrous material [6]. Thus, the objective of this study was to evaluate the effects supplementation of different formulations UMMB to heifers Peranakan Ongole fed rice straw based diets on their live body weight gain performance.

\section{Methods}

\subsection{Ingredient Composition of UMMB}

A technology was adopted for the preparation of UMMB by using locally available feed ingredients such as molasses, urea, rice bran, mineral mixture, milk powder, common salt and cement. The UMMB A consisted of molasses, urea, rice bran, mineral mixture, milk powder, common salt and cement at the level of $20 \%$, $2.5 \%, 55 \%, 1 \%, 5 \%, 4 \%$ and $12.5 \%$ respectively. The UMMB B consisted of molasses, urea, rice bran, mineral mixture, milk powder, common salt and cement at the level of $20 \%, 2.5 \%, 54 \%, 2 \%, 5 \%, 4 \%$ and $12.5 \%$ respectively. The difference of ingredient composition between UMMB A and UMMB B is in the percentage of rice bran and mineral mixture.

\subsection{Animals Feeding and Management}

A total of 15 heifers Peranakan Ongole breed were randomly allocated to three experimental groups. All experimental animal groups were daily fed a basal diet consisted of chopped rice straw and native grass field and had free access to water ad libitum throughout one month of the experimental period. Control group animals were daily fed basal diet without UMMB, group A were daily fed basal diet with UMMB (A) and group B were daily fed basal diet with UMMB (B) respectively. Urea-molasses multi-nutrient block were given once a week for each animal.

\subsection{Body Weight Measurement}

The body weight were measured weekly throughout the experiment of $4 \mathrm{wk}$. Estimating body weight based on their body length (measure from the point of shoulder to the point-of-rump or pin bone) and chest diameter (measure from a point slightly behind the shoulder blade, down the fore-ribs and under the body behind the elbow all the way around) using Lambourne and Schoorl equations.

$\mathrm{BW}=(\mathrm{HG})^{2} \times \mathrm{BL} / 10840$

BW: body weight $(\mathrm{kg})$

$\mathrm{HG}$ : heart girth $(\mathrm{m})$

BL: body length $(\mathrm{m})$

\subsection{Statistical Analysis}

Statistical analysis of the experimental data was carried out using the statistical software SPSS (Statistical Package for the Social Sciences) with ANOVA method. Significance was defined as $\mathrm{P}<0.05$ unless stated otherwise. 


\section{Results}

Effect of feeding UMMB on the body weight gain of heifers are shown in Table 1. A lot of research reports showed that UMMB can improve the body weight. The results showed that there was a difference of the average weight gain between control group and treatment group of UMMB A and UMMB B after four weeks of experimental periods. The average weight gain in the control group, UMMB A and UMMB B during the four weeks of the study period was $8.22 \pm 2.6 \mathrm{~kg}, 9.50 \pm 1.3 \mathrm{~kg}$ and $9.40 \pm 0.8 \mathrm{~kg}$ respectively. The findings are in agreement with those of [7], who observed that UMMB can increase body weight between 0.2 and $0.45 \mathrm{~kg}$ each day. Zhang reported that the average daily gain was $0.4867 \pm 0.0732 \mathrm{~kg}$ in the experiment group and $0.3468 \mathrm{~kg}$ in the control group during the period feeding of UMMB [8].

Table 1. Effect of Urea Molasses Multi nutrient Block (UMMB) on body weight gain in heifers in the district of Gunungkidul, DIY Province.

\begin{tabular}{llll}
\hline & initial weight (kg) & final weight (kg) & Average Weight Gain \\
\hline control & 239,25 & 247,48 & $8,22 \pm 2,6^{\mathrm{a}}$ \\
supplement UMMB A & 235,00 & 244,52 & $9,5 \pm 1,3^{\mathrm{b}}$ \\
supplement UMMB B & 233,77 & 243,17 & $9,4 \pm 0,8^{\mathrm{b}}$ \\
\hline
\end{tabular}

a,b,c different superscripts in the same row indicate significant difference $(\mathrm{P}<0.05)$

A similar response to UMMB supplementation also occurred on the increase of daily live weight gain of Ongole, Simmental, and Fries Holstein (FH) Cross Breed. The increase of daily live weight gain was higher with than without supplement [9]. Similar effects were observed in other ruminant species, such as ewes, sheep and Buffalo [10,11, 12]. According to Makkar et al. [13], UMMB supplements may influence the Heifers body weight through an increased microbial protein, digestibility and feed intake for a better balance of amino acids and energy absorption during nutrients intake. Moreover, Haresign and Cole [14] revealed that animals supplemented with UMMB digested the feed more efficiently than those without urea molasse multinutrient block supplementation.

The results revealed that there was significant difference in body weight of heifers Peranakan Ongole maintained under different treatments up to $4 \mathrm{wk}$ of the experiment. In agreement with the present findings, there is evidence to indicate that UMMB supplementation has a significant effect on daily body weight gain in limousine cattle crossbreed, crossbreed cows, working bullocks, goat, and small ruminants merino sheep $[15,16,17,18,19]$. However, several study showed that supplementation of UMMB had no significant difference effect in body weight of Bali cattle, cow and Mecheri ram lambs [20, 21, 22]. The differences in these results of the study may be due to the difference of the basal feed given, difference of experimental animals, period of experimental and difference of UMMB formulation or composition [23, 24, $15,25]$. From the various results study it was observed that UMMB technology has a benefit role to play in the efficient utilization of agro industrial by products and in meeting the nutritional needs of ruminants.

\section{Conclusions}

According to the results it can be concluded supplementation of urea molasses mineral block above the rice straw based on diet with some amount of native grass field had positive effect on the body average body weight gain. Moreover, based on statistical analyses, it can be concluded that supplementation of UMMB had significant difference effect on average weight gain in this study. The results showed that UMMB supplementation is an effective strategy to increase the body weight especially if the basal diet has a low quality such as rice straw. 


\section{References}

1. Garg, M.R., Sherasia, P.L., Bhanderi, B.M., Phondba, B.T., Shelke, S.K., Makkar, H.P.: Effects of feeding nutritionally balanced rations on animal productivity, feed conversion efficiency, feed nitrogen use efficiency, rumen microbial protein supply, parasitic load, immunity and enteric methane emissions of milking animals under field conditions. Animal Feed Science and Technology 179 (1-4), 24-35 (2013).

2. Perera, B.M.A.O., Jayasuriya, M.C.N.: The dairy industry in Sri Lanka: Current status and future directions for a greater role in national development. Journal of the National Science Foundation of Sri Lanka 36,115-126 (2008). doi:10.4038/jnsfsr.v36i0.8050

3. Tekeba, E., Wurzinger, M., Zollitsch, W.J.: Effects of dietary supplementation with urea molasses multi-nutrient block on performance of late lactating local ethiopian and crossbred dairy cows. International Journal of Technology Enhancements and Emerging Engineering Research 2(2), 25-32 (2014).

4. Sansoucy, R.: New developments in the manufacture and utilization of multinutrient blocksshort communication. FAO Animal Production and Health Paper 82, 78-83 (1995).

5. Wanapat, M., Kang, S., Polyorach, S.: Development of feeding systems and strategies of supplementation to enhance rumen fermentation and ruminant production in the tropics. Journal of Animal Science and Biotechnology 4, 2-11 (2013). doi: 10.1186/2049-1891-4-32

6. Wongnen, N.: Feed supplementation of dairy cattle with UMMB (urea-molasses multinutrient block) in the North Eastern region of Thailand. In: H.P.S. Makkar, M. Sánchez, A.W. Speedy (eds.) Feed supplementation blocks. pp. 111-124. Food and Agriculture Organization of The United Nations, Rome (2007).

7. Abutani, S. A., Rahim, S., Noverma: Respon pemberian blok suplemen berbasis bahan local terhadap pertambahan bobot sapi Bali [Response of supplementation of blocks made of local ingredients on body weight of Bali cattle]. Jurnal Sain Peternakan Indonesia 5 (1), 65-69 (2010). [In Bahasa Indonesia].

8. Salem, H.B.,, Nefzaoui, A., Makkar, H.P.S.: Feed supplementation blocks for increased utilization of tanniniferous foliages by ruminants. In: H.P.S. Makkar, M. Sánchez, A.W. Speedy (eds.) Feed suplementation blocks. pp. 185-205. Food and Agriculture of The United Nations, Rome (2007).

9. Suharyono, S., Sutanto, H., Purwanti, Y., Martanti, M., Agus, A., Ristianto, U.: The effect of urea molasses multi-nutrient and medicated block for beef cattle, beef and dairy cow. Atom Indonesia 40 (2), 77-87 (2014).

10. Rafiq, M., Mumtaz, S., Akhtar, N., Khan, M.F.: Effect of strategic supplementation with multinutrient urea molasses blocks on body weight and body condition score of Lohi sheep owned by tenants of Pakistan. Small Ruminant Research 70 (2-3), 200-208 (2007). doi: 10.1016/j.smallrumres.2006.03.005

11. Hossain, K.B., Sarker, N.R., Saadullah, M., Beg, M.A.H., Khan, T.M.: Effect of feeding straw supplementing with urea molasses block lick on the performance of sheep. Asian-Australasian Journal of Animal Sciences 8(3), 289-293 (1995). doi: 10.5713/ajas.1995.289

12. Perera, A.N.F., Perera, E.R.K., Abeygunawardane, H.: Development, use, and impact of feed supplementation blocks: Experiences in Sri Lanka. In: H.P.S. Makkar, M. Sánchez, A.W. Speedy (eds.) Feed supplementation blocks. pp. 125-135. Food and Agriculture of The United Nations, Rome (2007). 
13. Makkar, H.P.S., Sánchez, M., Speedy, A.: Feed supplementation blocks. Food and Agriculture of The United Nations, Rome (2007)

14. Haresign, W., Cole, D.J.A.: Recent advances in animal nutrition. pp. 173-185. Elsevier, Nottingham (1991).

15. Li, H., Hou, Z., Yang, Q., Li, Q., Wang, K., Lang, L., Lin, P., et al.: Study the effect of urea molasses multinutrient block on fattening cattle. Journal of Food, Agriculture and Environment 12 (2), 573-578 (2014).

16. Alam, M.G.S., Ul-Azam, S., Khan, J.: Supplementation with urea and molasses and body weight, milk yield and onset of ovarian cyclicity in cows. Journal of Reproductive and Development 52(4), 529-535 (2006).

17. Kerketta, N., Victor, V.M., Chandraker, A.K., Jogdand, S.V.: Effect of urea molasses mineral block as feed supplement on body weight gain and haemato-biochemical parameters of working bullocks. International Journal of Agriculture Innovations and Research 5(6), 917-920 (2017).

18. Murniati, T., Idrus, M., Toleng, A.L., Rahardja, D.P., Ako, A., Jusoff, K.: Optimalization of supplementation time for improving reproductive effeciency and gene expression of goats. World Applied Science Journal 26(26), 100-104 (2013).

19. Hatungimana, E., Ndolisha, P.: Effect of urea molasse block supplementation on growth performance of sheep. International Journal of Novel Research in Life Sciences 2(3), 38-43 (2015).

20. Nurwahidah, J., Tolleng, A.L. Hidayat, M.N.: Pengaruh pemberian pakan konsentrat dan urea molases blok (UMB) terhadap pertambahan berat badan sapi potong. [Impact of concentrated feeding and urea molases block (UMB) on beef cattle body weight increase]. Jurnal Ilmu dan Industri Peternakan 2(2), 111-121 (2016). [In Bahasa Indonesia].

21. Suharyono, S.: Development of feed supplement urea molasses multinutrient block (UMMB) using protein source from soy bean flour and Gliricidia sepium (Gs) for ruminant animal. Jurnal Ilmiah Aplikasi Isotop dan Radiasi 10(1), 11-21 (2014).

22. Dharan, M., Thiruvenkadan, A.K., Saravanakumar, V.R.: Effect of concentrate and urea molasses mineral block (UMMB) supplementation on the growth and feed consumption of Mecheri lambs under intensive rearing. Indian Journal of Animal Research 50, 382-386 (2016).

23. Alemu, T., Chairatanayuth, P., Vijchulata, P., Tudsri, S.: The potential of urea treated maize stover for growth performance of weaned crossbred calves. Kasetsart Journal (Natural Science) 39, 638-646 (2005).

24. Fesaha, G., Urge, M.: Comparison of supplementing urea-molasses block and urea- atela blocks on body weight change and carcass characteristics of male blackhead ogaden sheep fed natural pasture hay. Journal of Biology, Agriculture and Healthcare 4(20), 136-141(2014).

25. Dharan, M., Jayachandran, S., Thiruvenkadan, A., Singh, D.A.P., Sivakumar, K.: Effect of concentrate and urea molasses mineral block supplementation on the blood biochemistry of off season Mecheri lambs. Indian Journal of Animal Research 49(3), 409-412 (2015). 